\title{
SELECTIVE INHIBITION OF HERPES SIMPLEX VIRUS RIBONUCLEOSIDE DIPHOSPHATE REDUCTASE BY DERIVATIVES OF 2-ACETYLPYRIDINE THIOSEMICARBAZONE
}

\author{
Steven R. Turk, Charles Shipman, JR. and John C. DraCh* \\ Interdepartmental Graduate Program in Medicinal Chemistry and Department of Oral Biology, School \\ of Dentistry, The University of Michigan, Ann Arbor, MI 48109, U.S.A.
}

(Received 24 June 1985; accepted 18 October 1985)

\begin{abstract}
The effects of thiosemicarbazone derivatives of 2-acetylpyridine on mammalian and viral ribonucleoside diphosphate reductases were investigated. The enzymes were partially purified from uninfected and herpes simplex virus type-1 (HSV-1)-infected KB cells by sequential salt fractionation with streptomycin sulfate and ammonium sulfate and by affinity chromatography on ATP-agarose. The five thiosemicarbazone derivatives investigated were all potent inhibitors of the virus-induced reductase Fifty percent inhibitory concentrations ( $\mathrm{IC}_{50}$ values) range from 2 to $13 \mu \mathrm{M}$. Four of the five derivatives also were inhibitors of the host cell reductase $\left(\mathrm{IC}_{50}\right.$ values $\left.=7-34 \mu \mathrm{M}\right)$. A semicarbazone was inactive against the cellular enzyme and relatively weak as an inhibitor of the viral enzyme $\left(\mathrm{IC}_{50}=340 \mu \mathrm{M}\right)$. Four of the six compounds were preferential inhibitors of the viral reductase based on a comparison of $\mathrm{IC}_{50}$ values (5- to $>85$-fold difference). Kinctic experiments revealed that inhibition of the HSV-1 reductase by the thiosemicarbazones was noncompetitive with respect to CDP and dithiothreitol. A comparison of the inhibitory effects of 2-acetylpyridine thiosemicarbazone itself on viral reductase and on virus replication in vitro demonstrated a similarity in the dose-response relationships for the two parameters. This observation supports the hypothesis that the HSV-induced ribonucleoside diphosphate reductase is an important target for the design of antiviral drugs.
\end{abstract}

\begin{abstract}
A series of thiosemicarbazone derivatives of 2-acetylpyridine has been synthesized by Klayman et al. $[1,2]$ as potential antimalarial agents. Screening of the compounds against other pathogenic organisms revealed that the compounds also possessed additional antiparasitic [3], antimicrobial [4, 5], and antineoplastic [6] activity. We have since discovered that a number of these compounds are active against herpes simplex virus types 1 and 2 (HSV-1 and HSV2) and that some of the derivatives inhibit the in vitro replication of the virus to a greater extent than they inhibit cellular DNA or protein synthesis [7]. To date we have examined 111 derivatives and have found that certain compounds are active both in vitro and in a cutaneous herpes guinea pig model [8].

Extensive study into the mechanism of action of these derivatives in uninfected mammalian cells has led us to conclude that inhibition of ribonucleotide reductase (ribonucleoside diphosphate reductase, EC 1.17.4.1) is the primary cytotoxic effect of these compounds. + This finding is in agreement with reports by others on the mode of action of related classes of thiosemicarbazones in uninfected cells [9]. Mammalian ribonucleotide reductase, a key enzyme in the de novo synthesis of DNA, catalyzes the
\end{abstract}

* Author to whom correspondence should be addressed at the School of Dentistry, The University of Michigan, Ann Arbor, MI 48109.

† S. R. Turk, C. Shipman, Jr., C. M. Reinke and J. C. Drach, Twenty-third Interscience Conf. Antimicrob. Agents Chemother., Las Vegas, NV (1983). reduction of ribonucleoside diphosphates to the corresponding 2'-deoxyribonucleoside diphosphates [10].

Herpes simplex viruses induce the formation of a unique ribonucleoside diphosphate reductase following infection [11-15]. Unlike cellular reductase, the HSV-induced enzyme is free of allosteric control [16-18]. This permits the buildup of large deoxynucleotide pools necessary for viral DNA replication. Cohen et al. [19] have presented evidence that the virus-induced enzyme is composed of two non-identical subunits ( $\mathrm{H} 1$ and $\mathrm{H} 2$ ) which are different from the corresponding subunits (M1 and M2) of the mammalian enzyme.

The fact that cellular and viral reductases are biochemically distinct [16-18] suggests that they may be differentially affected by inhibitors of ribonucleotide reduction. If so, the virus-induced reductase might have the potential to serve as a target for antiviral drugs. There is, however, little evidence in the literature to support this hypothesis. For example, the two enzymes appear to be about equally sensitive to hydroxyurea [17-20]: this led Nutter et al. [20] to speculate that the HSV-2 reductase is not an effective target for antiviral drugs. Similarly, the viral enzyme is slightly less sensitive to guanazole and 4-methyl-5-amino-1-formylisoquinoline thiosemicarbazone (MAIQ) than is the cellular enzyme $[19,21]$. On the other hand, Nakayama et al. [22] found the viral enzyme to be slightly more sensitive to inhibition by $E-5$-(2-bromovinyl)dUTP and 2'-fluoro-5-iodo-ara-CTP than was the 
cellular enzyme. Similarly, Shannon et al. ${ }^{*}$ found the viral reductase to be 20 -fold more sensitive than the cellular enzyme to the 5 -triphosphate of the antiviral drug vidarabine (ara-A). This observation, however, conflicts with those of Langelier and Buttin [17] and Averett et al. [18] who could not demonstrate inhibition of the viral enzyme by ara-A-triphosphate.

In this study we have examined whether HSV1 -induced ribonucleoside diphosphate reductase is sensitive to derivatives of 2-acetylpyridine thiosemicarbazone and whether this inhibition is responsible for the antiviral effect of these compounds. We have found that these derivatives not only inhibit the virus-specified enzyme, but that some do so without appreciably inhibiting the cellular enzyme. To our knowledge, such potent and selective inhibition of HSV ribonucleotide reductase has not been reported previously,

\section{MATERIALS AND METHODS}

Chemicals. Nucleotides, nucleosides, bovine serum albumin (fraction $\mathrm{V}$ ) and dithiothreitol (DTT) were purchased from the Sigma Chemical Co., St. Louis, MO. HEPES [4-(2-hydroxyethyl)-1piperazine-ethanesulfonic acid] buffer was obtained from the Calbiochem-Behring Corp., La Jolla, CA. Agarose-hexane-ATP (ATP-agarose, type 3, linked via $\mathrm{C}-8$ of the purine ring) was obtained from Pharmacia P-L Biochemicals, Inc., Milwaukee, WI. Streptomycin sulfate was obtained from Pfizer Laboratories, New York, NY. Ammonium sulfate (ultra pure grade) was purchased from Schwartz Mann, Cambridge, MA. $\left[5^{-3} \mathrm{H}\right] \mathrm{CDP}$ (16 to $19.3 \mathrm{Ci} / \mathrm{mmole}$ ) was obtained from the Amersham Corp., Arlington Heights, IL. Thiosemicarbazone and semicarbazone derivatives of 2-acetylpyridine were provided by Dr. Daniel L. Klayman, Walter Reed Army Institute of Research, Washington, DC. Methisazone was obtaincd from Dr. P. D. Cook, Warner-Lambert/ Parke-Davis Co., Ann Arbor, MI.

Cell culture techniques and virus propagation. KB cells, an established human cell line derived from an epidermoid carcinoma of the mouth, and the HF strain of HSV-1 were obtained from Dr. G. H. Cohen, University of Pennsylvania, Philadelphia, PA. The routine growth and passage of cells, the propagation and titration of virus stocks, and the detection of mycoplasma contamination have been described previously [23].

Enzyme purification. Uninfected $\mathrm{KB}$ cells were grown to mid-log phase as monolayers either in 32oz. glass prescription bottles (Brockway Glass Co., Brockway, NJ) or in $850 \mathrm{~cm}^{2}$ plastic roller bottles (Corning Glassworks, Corning, NY). Cells were harvested by scraping, were washed in HEPES-buffered saline [24], and were collected by centrifugation at $800 \mathrm{~g}$. Cell pellets were stored at $-76^{\circ}$ until needed. Monolayers infected with HSV-1 at a multiplicity of infection (moi) of five plaque-forming units per cell were harvested by similar procedures $12 \mathrm{hr}$ postinfection. In our hands, this combination of moi and

* W. M. Shannon, R. W. Brockman, G. Arnett and S Shaddix, First Am. Soc. Virol. Meeting, Ithaca, NY (1982). incubation time provided the highest enzyme specific activity.

All subsequent steps were done at $0-5^{\circ}$. Pellets were thawed, resuspended in buffer A $(20 \mathrm{mM}$ HEPES, pH 7.6, 2 mM DTT), and sonicated in eight $15-\mathrm{sec}$ pulses using a Bronwill Sonicator (Bronwill Scientific Inc., Rochester, NY). Lysates were clarified by centrifugation at $100,000 \mathrm{~g}$ for $60 \mathrm{~min}$. The resulting supernatants were fractionated by sequential protein precipitations at final concentrations of $1 \%$ streptomycin sulfate, $27 \%$ saturation with $\left(\mathrm{NH}_{4}\right)_{2} \mathrm{SO}_{4}$ and $41 \%$ saturation with $\left(\mathrm{NH}_{4}\right)_{2} \mathrm{SO}_{4}$ performed by the method of Huszar and Bacchetti [16]. Pellets from the salt fractions were redissolved in 1 $2 \mathrm{ml}$ of buffer $\mathrm{A}$ and dialyzed against buffer $\mathrm{A}$, along with aliquots of the $100,000 \mathrm{~g}$ supernatant fraction.

Selected fractions were further purified by affinity chromatography utilizing ATP-agarose by a method patterned after that of Spector and Averett $[18,25]$. Protein from the salt fractions was first reprecipitated at $50 \%\left(\mathrm{NH}_{4}\right)_{2} \mathrm{SO}_{4}$ saturation, pelleted, resuspended in $0.5 \mathrm{ml}$ buffer $\mathrm{B}(20 \mathrm{mM}$ HEPES, pH $7.6,2 \mathrm{mM}$ DTT, $2 \mathrm{mM}$ magnesium acetate), and dialyzed against buffer $\mathrm{B}$ as described previously. After clarification by centrifugation, the preparation was applied to an $0.8 \times 12.3 \mathrm{~cm}$ column of ATP-agarose and eluted sequentially with buffer $B$ and buffer $B$ containing either $1 \mathrm{M} \mathrm{KCl}$ or $2 \mathrm{mM} \mathrm{ATP}$ at a flow rate of $3-5 \mathrm{ml} / \mathrm{hr}$. The two protein fractions were pooled and dialyzed against buffer $B$. All preparations were stored at $-76^{\circ}$.

Enzyme assays. Separate, selective assay conditions were used for the viral and cellular reductases. Based upon the observations of Averett et al. [18], we found that the viral enzyme was fully active in the absence of ATP and $\mathrm{Mg}^{2+}$, whereas the cellular enzyme had an absolute requirement for ATP and $\mathrm{Mg}^{2+}$. This difference plus different DTT concentrations and $\mathrm{pH}$ optima provided conditions under which cellular reductase activity was inhibited $>97 \%$ when assayed under viral assay conditions and viral reductase activity was inhibited $>99 \%$ when assayed under cellular assay conditions.

The standard reaction mixture for assay of the viral reductase contained, in a final volume of $100 \mu \mathrm{l}$, $60 \mathrm{mM}$ HEPES at $\mathrm{pH} 8.0,26 \mathrm{mM}$ DTT, $1-11 \mu \mathrm{Ci}$ of $\left[{ }^{3} \mathrm{H}\right] \mathrm{CDP}(0.52-12 \mu \mathrm{M})$, and enzyme. In contrast, reaction mixtures for assay of the cellular reductase contained HEPES at pH $7.2,7 \mathrm{mM}$ DTT, $1 \mathrm{mM}$ ATP, $1 \mathrm{mM}$ magnesium acetate, $\left[{ }^{3} \mathrm{H}\right] \mathrm{CDP}$, and enzyme. After incubation at $37^{\circ}$ for $5-30 \mathrm{~min}$, reactions were terminated by heating at $95^{\circ}$ for $2 \mathrm{~min}$.

Depletion of substrate $\left(\left[{ }^{3} \mathrm{H}\right] \mathrm{CDP}\right)$ by interfering enzyme activities was assayed by TLC on polyethyleneimine (PEI)-cellulose [26]. Aliquots (3 $\mu \mathrm{l})$ were removed from reaction tubes and applied to TLC plates prespotted with Cyd, CMP, CDP and CTP. Ascending development in $0.1 \mathrm{M} \mathrm{LiCl}-1 \mathrm{~N}$ acetic acid separated the standards. Because of the low amount of reduction during the assays $(<5 \%)$, no attempt was made to separate the deoxy analogs from their ribosyl counterparts (mobilities identical). The four distinct areas were visualized under u.v. light $(254 \mathrm{~nm})$, cut from the plates, and eluted with $0.75 \mathrm{ml}$ of $1 \mathrm{M} \mathrm{MgCl}_{2}$. After the addition of $5 \mathrm{ml}$ of Aqueous Counting Scintillant (Amersham Corp.), 
label was quantitated in a liquid scintillation spectrometer. The amount of radioactivity which cochromatographed with the nucleoside triphosphate spot in assays containing ATP and $\mathrm{Mg}^{2+}$ (cellular assay reaction mixtures) was taken as a measure of nucleotide kinase activity. The amount of radioactivity which co-chromatographed with the nucleoside monophosphate and nucleoside spots in assays without ATP and $\mathrm{Mg}^{2+}$ (viral assay reaction mixtures) was taken as a measure of phosphatase activity.

$\mathrm{HClO}_{4}(20 \mu \mathrm{l})$ was added to the remainder of the reaction mixtures to give a final concentration of $1 \mathrm{~N}$. Incubation at $95^{\circ}$ for $15 \mathrm{~min}$ converted nucleoside di- and triphosphates to monophosphates. Mixtures were neutralized to $\mathrm{pH} \mathrm{6-7}$ with $20 \mu \mathrm{KOH} / \mathrm{K}_{2} \mathrm{CO}_{3}$, the precipitate was pelleted, and $5 \mu \mathrm{l}$ of the supernatant fraction was applied to PEI-cellulose TLC plates prespotted with UMP, CMP, dCMP, dUMP, dTMP and Cyd. Ascending development in $\mathrm{H}_{2} \mathrm{O}$ saturated with boric acid and neutralized to $\mathrm{pH} 7$ separated all pyrimidine deoxyribonucleoside monophosphates from corresponding ribonucleoside monophosphates and from nucleosides plus bases. These three distinct areas were cut from the plates and eluted, and label was quantitated as previously mentioned. The amount of radioactivity which cochromatographed with the deoxyribonucleotide spot was used as the measure of reductase activity.

Protein determination. Protein was determined by the method of Peterson [27]. Bovine serum albumin was used as the standard.

\section{RESULTS}

Isolation of viral and cellular ribonucleotide reductases. HSV-1-induced reductase was separated from the host cell enzyme by salt fractionation with $\left(\mathrm{NH}_{4}\right)_{2} \mathrm{SO}_{4}$ using the methodology of Huszar and Bacchetti [16]. The desired viral enzyme precipitated at $27 \%$ saturation. Salt fractionation of uninfected cells gave a source of host cell reductase which precipitated between 27 and $41 \%$ saturation. The two enzyme activities differed biochemically as has been reported by others [16-18]. For example, the cellular enzyme had an absolute requirement for ATP (maximum activity at $1 \mathrm{mM}$ ) whereas the viral enzyme was inhibited in its presence. The cellular enzyme was approximately sixty times more sensitive to inhibition by dTTP, a known allosteric inhibitor of ribonuclcotide reductase, than was the viral enzyme [50\% inhibitory concentrations ( IC $_{50}$ values) $=8$ and $450 \mu \mathrm{M}$ respectively]. The two enzymes also differed in their $\mathrm{pH}$ optima and in their requirements for DTT as detailed in Materials and Methods.

The degradation of substrate $\left(\left[{ }^{3} \mathrm{H}\right] \mathrm{CDP}\right)$ by our preparations also was examined. Table 1 illustrates that the fractionation procedure for infected cells removed $96 \%$ of the kinase activity and $98 \%$ of the phosphatase activity from the 0 to $27 \%\left(\mathrm{NH}_{4}\right)_{2} \mathrm{SO}_{4}$ fraction while leaving $96 \%$ of the reductase activity. Thus, when examined under viral reductase assay conditions (no ATP or $\mathrm{Mg}^{2+}$, thereby suppressing kinase activity), the preparation was highly enriched in reductase activity and was low in interfering activities.

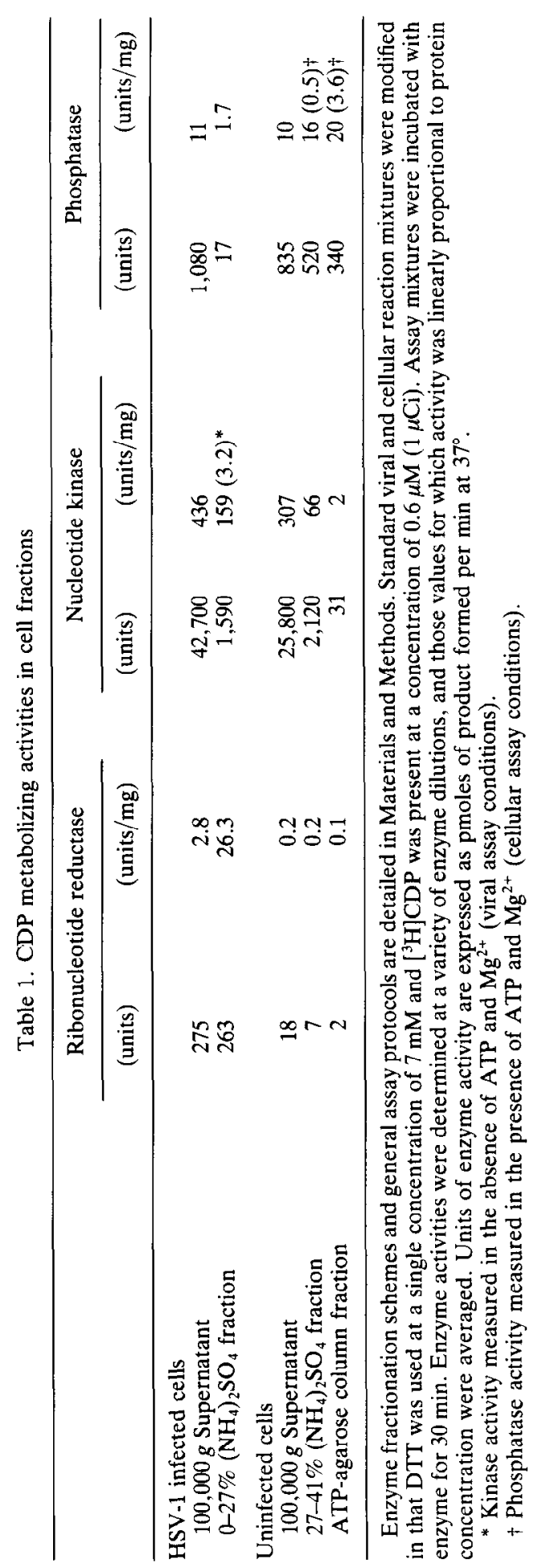


The fractionation procedure for uninfected cells resulted in the elimination of 91 and $38 \%$, respectively, of the kinase and phosphatase activities from the 27 to $41 \%\left(\mathrm{NH}_{4}\right)_{2} \mathrm{SO}_{4}$ fraction. There was, however, a $65 \%$ loss of reductase activity resulting in a low ratio of reductase to kinase. To remove additional kinase, this fraction was passed through an ATP-agarose column using the method of Spector and Averett [25]. This procedure reduced the kinase activity to $0.1 \%$ of that found in the $100,000 \mathrm{~g}$ supernatant fraction. Even though reductase activity also was lost, the striking loss of kinase resulted in a 20 fold improvement of the ratio of reductase to kinase (Table 1). The apparent increases in phosphatase specific activity may have been from increases in available substrate due to decreases in kinase activity. Nevertheless, the amount of phosphatase activity was not significant when measured under cellular reductase assay conditions (ATP and $\mathrm{Mg}^{2+}$ present). Even though this procedure did not eliminate all degradation of substrate, we found that $80 \%$ of CDP remained at the end of $30-\mathrm{min}$ incubations with the ATP-agarose-purified preparation compared to $14 \%$ after $30-\mathrm{min}$ incubations with the $\left(\mathrm{NH}_{4}\right)_{2} \mathrm{SO}_{4}$ fraction. Significantly, no differences in inhibition by the thiosemicarbazones were observed between the $\left(\mathrm{NH}_{4}\right)_{2} \mathrm{SO}_{4}$-purified and the columntreated preparations.

Effects of thiosemicarbazone derivatives on viral and cellular ribonucleotide reductase. Using the enzymes derived from the salt fractions and the ATPagarose column (listed in Table 1), we determined dose-response relationships for 2-acetylpyridine thiosemicarbazone (the parent compound), four $\mathrm{N}^{4}$ monosubstituted derivatives and 2-acetylpyridine semicarbazone. Table 2 illustrates that all of the derivatives were inhibitors of HSV-1-induced ribonucleotide reductase, although the semicarbazone analog (compound 6) was significantly less potent than the corresponding thiosemicarbazone (compound 1). The parent compound and the $\mathrm{N}^{4}$-methyl, -allyl and -benzyl derivatives (compounds 1-4) also inhibited the cellular enzyme. Based upon a comparison of $\mathrm{IC}_{50}$ values, the parent compound, the $\mathrm{N}^{4}$ methyl and -picolyl derivatives and the semicarbazone (compounds 1, 2, 5 and 6) were 5, 8, $>85$ and $>16$ times, respectively, more potent as inhibitors of the viral enzyme. In contrast, since there was complete overlap of $95 \%$ confidence intervals, compounds 3 and 4 showed no selectivity

Table 2. Inhibition of viral and cellular ribonucleoside diphosphate reductase by derivatives of 2-acetylpyridine thiosemicarbazone

\begin{tabular}{|c|c|c|c|c|}
\hline \multirow[b]{2}{*}{ No. ${ }^{+}$} & \multirow{2}{*}{\multicolumn{2}{|c|}{$\begin{array}{l}\mathrm{CH}_{3} \\
=\mathrm{N}-\mathrm{NH}-\stackrel{\mathrm{X}}{\mathrm{C}}-\mathrm{NH}-\mathrm{R} \\
\mathrm{R}\end{array}$}} & \multicolumn{2}{|c|}{${ }^{1 C_{50}}{ }^{*}(\mu \mathrm{M})$} \\
\hline & & & $\begin{array}{l}\text { HSV }-1 \text { induced } \\
\text { reductase }\end{array}$ & Ccllular reductase \\
\hline 1 & $\mathrm{~S}$ & $\mathrm{H}$ & $2.0(1.5-2.5)$ & $10(4.9-22)$ \\
\hline 2 & $\mathrm{~S}$ & $\mathrm{CH}_{3}$ & $4.2(3.4-4.8)$ & $34(11-150)$ \\
\hline 3 & $\mathrm{~S}$ & $\mathrm{CH}_{2} \mathrm{CH}=\mathrm{CH}_{2}$ & $9.4(5.5-16)$ & $12(0.47-140)$ \\
\hline 4 & $\mathrm{~S}$ & & $7.7(5.6-11)$ & $6.7(4.2-11)$ \\
\hline 5 & $\mathrm{~S}$ & $\mathrm{H}_{2}-$ & $13(6.7-25)$ & $>1100$ \\
\hline 6 & $\mathrm{O}$ & $\mathrm{H}$ & $340(140-1200)$ & $>5600$ \\
\hline
\end{tabular}

Reductase assays were performed by the general protocol detailed in Materials and Methods using the $\left(\mathrm{NH}_{4}\right)_{2} \mathrm{SO}_{4}$ and affinity column-purified protein fractions characterized in Table 1. Enzyme dilutions were used such that a minimum of $1,500 \mathrm{cpm}$ were converted to product in control assays. Six to eight selected concentrations of compounds were assayed at a minimum of the two following substrate concentrations: $0.5 \mu \mathrm{M}\left[{ }^{3} \mathrm{H}\right] \mathrm{CDP}\left(1 \mu \mathrm{Ci}\right.$; approximately $\left.0.5 \times K_{m}\right)$ and $12 \mu \mathrm{M}\left[{ }^{3} \mathrm{H}\right] \mathrm{CDP}\left(2-4 \mu \mathrm{Ci}\right.$; approximately $\left.10 \times K_{m}\right)$. No apparent difference in response was noted at the different substrate levels. Compounds were initially dissolved in dimethyl sulfoxide (DMSO) and assayed at a final concentration of $2.5 \% \mathrm{DMSO}$.

* Each compound was assayed in two to four experiments and the resulting data were combined to construct a single dose-response curve for each enzyme. The $50 \%$ inhibitory concentration $\left(\mathrm{IC}_{50}\right)$ values and corresponding $95 \%$ confidence intervals listed in parentheses were determined by linearly regressing probit values of the percent inhibition of reductase activity against log drug concentrations using the methods described by Goldstein [28].

+ Commonly employed systemalic chemical names for the compounds are as follows: compound 1 , 2-acetylpyridine thiosemicarbazone; compound 2, 2-acetylpyridine 4-methyl-3-thiosemicarbazone; compound 3, 2-acetylpyridine 4-allyl-3-thiosemicarbazone; compound 4, 2-acetylpyridine 4-benzyl-3-thioscmicarbazonc; compound 5, 2-acetylpyridine 4-picolyl-3-thiosemicarbazone; and compound 6, 2-acetylpyridine semicarbazone. 


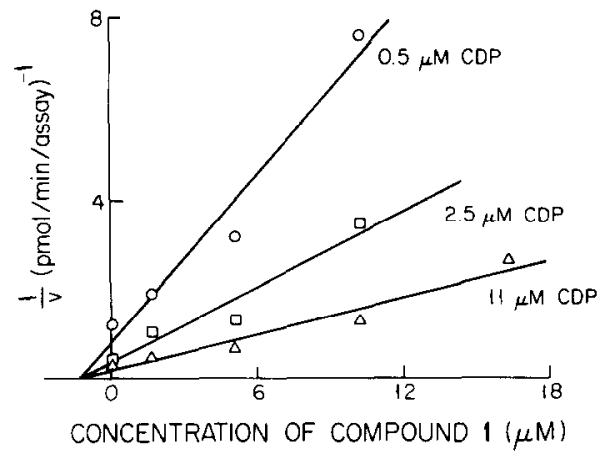

Fig. 1. Dixon plot of the inhibition of virus-induced ribonucleoside diphosphate reductase by 2 -acetylpyridine thiosemicarbazone (compound 1). Viral reductase assays were performed by the general protocol detailed in Materials and Methods using the $\left(\mathrm{NH}_{4}\right)_{2} \mathrm{SO}_{4}$ fraction characterized in Table 1. Standard viral reaction mixtures contained $18 \mu \mathrm{g}$ enzyme and $\left[{ }^{3} \mathrm{H}\right] \mathrm{CDP}(1$ or $2 \mu \mathrm{Ci} /$ assay) at the concentrations indicated; incubations were for $15 \mathrm{~min}$. Rate of product formation was linear with respect to time for at least $15 \mathrm{~min}$. The $r^{2}$ values of the regression lines are 0.95 , 0.94 and 0.98 for $0.52,2.5$ and $11 \mu \mathrm{M}$ CDP respectively. The common intersection of the three lines on the $x$ axis indicates noncompetitive inhibition [30]. A doublereciprocal plot of the data according to Lineweaver and Burk (not shown) gave a common intersection on the $x-$ axis, also indicative of noncompetitive inhibition [30]

between inhibition of viral and cellular reductases. Methisazone (1-methylisatin- $\beta$-thiosemicarbazone; MIBT), reported to possess antiviral activity against vaccinia but poor activity against HSV-1 [29], did not inhibit the viral reductase at concentrations of up to $107 \mu \mathrm{M}$ (data not shown).

Kinetic properties of ribonucleotide reductases. The kinetic properties of ribonucleotide reductase activity and its inhibition were examined. $K_{m}$ concentrations for CDP (derived from Woolf plots) obtained in four and two separate experiments were 1.2 and $2.2 \mu \mathrm{M}$ for viral and cellular reductases respectively. Inhibition of viral reductase by 2 -acetylpyridine thiosemicarbazone (compound 1) was noncompetitive with respect to CDP (Fig. 1). From this plot and another experiment, an average $K_{i}$ concentration of $1.4 \mu \mathrm{M}$ was derived. A similar experiment with cellular reductase gave a $K_{i}$ concentration of $1.2 \mu \mathrm{M}$. Inhibition of viral reductase by the $\mathrm{N}^{4}$-methyl derivative (compound 2) also was noncompetitive, with a $K_{i}$ concentration of $3.6 \mu \mathrm{M}$.

The effect of DTT on the inhibition of viral reductase by 2 -acetylpyridine thiosemicarbazone also was examined. Reductase activity was measured at different fixed concentrations of DTT in the presence of selected concentrations of drug. A plot of the reciprocal of enzyme velocity versus drug concentration was made for each DTT concentration and indicated that inhibition was noncompetitive with respect to DTT (data not presented).

Comparison of the inhibitory effects of 2-acetylpyridine thiosemicarbazone on viral reductase and on virus replication. The effect of the parent compound on these parameters was compared as a test of the hypothesis that inhibition of the viral reductase

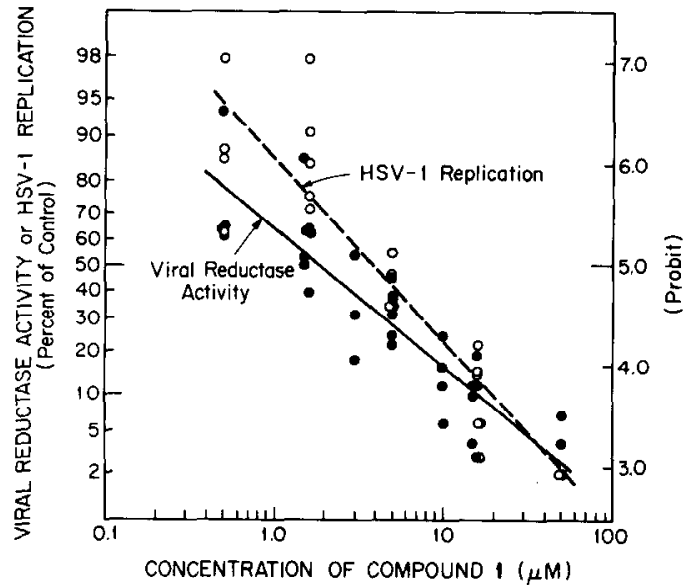

Fig. 2. Comparison of inhibition of viral ribonucleoside diphosphate reductase with inhibition of the in vitro replication of HSV-1 by 2-acetylpyridine thiosemicarbazone (compound 1). Reductase inhibition data (O) used to determine the $\mathrm{IC}_{50}$ given in Table 2 are presented and represent the combined results of three experiments. Virus replication data $(O)$, representing the combined results of two yield reduction experiments, were reported previously [7] Probit values of percent inhibition were linearly regressed against log drug concentration using the methods described by Goldstein [28]. The $r^{2}$ values of the regression lines are 0.82 and 0.88 for reductase and virus replication inhibition respectively. The identity of the two dose-response curves was tested by calculating $P$ values for the equality of regressions and slopes [31].

was responsible for inhibition of virus replication. Dose-response relationships were constructed and compared (Fig. 2). Visual inspection of the data show that inhibition of viral reductase is similar to inhibition of virus replication. Statistical comparison of the two dose-response lines indicated that the two lines were separate (comparison of slopes: $P=0.013$, comparison of regressions: $\mathrm{P}<0.001$ ) with a slightly greater inhibition of reductase activity. Although no simple comparison of dose-response effects on potentially related phenomena can prove a causal relationship, a marked dissimilarity can disprove such a relationship. In this case, because inhibition of the two phenomena is similar and because inhibition of the enzyme is slightly greater than inhibition of virus replication-and not vice versa-a causal relationship is possible.

\section{DISCUSSION}

Using the enzyme preparations described above, four compounds were identified that are more potent inhibitors of the viral enzyme than of the cellular enzyme (Table 2). With the possible exception of ara-A-5'-triphosphate, no other compounds have been reported possessing such a large degree of selectivity (5- to $>85$-fold difference) for the viral enzyme. Since cellular reductase was not inhibited $50 \%$ by compounds 5 and 6 at the highest concentrations tested, the selectivities for these two compounds may be even higher than noted.

Thiosemicarbazone derivatives are known to be 
potent chelating agents, forming coordination complexes with such transition metals as cobalt, nickel, copper and zinc [32]. These compounds are particularly strong chelators of iron. Moore et al. [33] found that inhibition of mammalian ribonucleotide reductase activity correlates directly with the ironchelating potency of a series of isoquinoline compounds. A similar result was seen here; the semicarbazone (compound 6) was significantly $(>170$ times) less inhibitory to either viral or cellular reductase than was the corresponding thiosemicarbazone (compound 1).

Insight into the mechanism of inhibition of mammalian ribonucleotide reductase by thiosemicarbazones was provided recently by Thelander and Gräslund [34]. They showed that the iron chelate of 1-formylisoquinoline thiosemicarbazone destroys the tyrosine free radical at the active site of the M2 subunit of reductase in a reaction requiring oxygen. They proposed that the ferrous chelate of the compound reacts with oxygen in a redox process leading to destruction of the radical via a one-electron reduction. If this mechanism is correct, the fact that the uncoordinated compounds used in this study inhibited reductase in the absence of added iron may result from the derivatives scavenging iron found as impurities in reaction components or enzyme preparations.

The reported effects of thiol reducing agents on inhibition of mammalian ribonucleotide reductase by thiosemicarbazones are somewhat inconsistent. Moore et al. [33] found that inhibition by 1-formylisoquinoline thiosemicarbazone is partially competitive with respect to DTT. Preidecker et al. [35] found that inhibition by MAIQ is uncompetitive with respect to thioredoxin. Competition also has been observed between DTT and another reductase inhibitor, hydroxyurea [36]. In the three reports, the true relationships may have been obscured due to the presence of various amounts of iron present in the assays, resulting in indeterminate redox reactions with the thiol reducing agents.

In this study inhibition of the viral reductase by compound 1 was noncompetitive with respect to DTT. The difference between these and previous results may simply be due to the absence of iron in our enzyme assays. Alternatively, the results may suggest a difference between the active sites of cellular and viral reductases. The active sites are thought to possess redox active sulfhydryl groups. Binding of an inhibitor to the iron atom or tyrosine free radical at the mammalian active site may sterically compete with the approach of thiol reducing agents needed to regenerate the sulfhydryl groups inactivated during catalysis, leading to competition between the thiol and drug. If the active site of the viral reductase were larger, steric hindrance would not occur and inhibition of drug would be noncompetitive with respect to thiol. The noncompetitive nature of compounds 1 and 2 with respect to CDP further suggests that the substrate and inhibitor sites on the viral reductase are spatially separate.

The differences between the kinetic parameters measured for the two enzymes were relatively small. The average $K_{m}$ for CDP was slightly lower for viral reductase $(1.2 \mu \mathrm{M})$ than for cellular reductase
$(2.2 \mu \mathrm{M})$. Previously reported $K_{m}$ concentrations for HSV-induced reductase range from 0.65 to $12 \mu \mathrm{M}$ $[18,37]$ whereas $K_{m}$ concentrations for mammalian cellular reductases range from 3.5 to $30 \mu \mathrm{M}$ [37-40]. The values obtained here were of a similar magnitude, lying near the lower ends of the reported ranges.

The five thiosemicarbazone derivatives described herein also are potent inhibitors of the in vitro replication of $\mathrm{HSV}-1$ ( $\mathrm{IC}_{50}$ values range from 0.5 to $6 \mu \mathrm{M}$ ) [8]. As inhibitors of HSV-1 ribonucleotide reductase, their $\mathrm{IC}_{50}$ values range from 2 to $13 \mu \mathrm{M}$ (Table 2). The similarity between these $50 \%$ inhibitory concentrations raised the possibility that inhibition of reductase may be responsible for inhibition of virus replication. A closer examination of the dose-response relationships for the parent compound 1 (Fig. 2) better illustrates the similarity between the two effects. The fact that viral reductase is slightly more sensitive to inhibition than is in vitro replication of virus suggests to us that inhibition of the viral enzyme is sufficient to account for the antiviral activity of this compound.

This conclusion is opposite that reached by Nutter et al. [20]. They found that inhibition of viral ribonucleotide reductase by hydroxyurea did not correlate well with inhibition of HSV-2 replication. They also found that most viral ribonucleotide reductase activity was not needed for virus replication and concluded that ". . . virus ribonucleotide reductase is not an effective target for developing anti HSV-2 compounds". Our correlation data, of course, do not prove causality but the data are consistent with a causal relationship. Together with the observation that viral ribonucleotide reductase is needed for HSV-1 replication [15], we conclude that this enzyme is an important target for the development of antiviral drugs.

Acknowledgements-S. R. T. was supported by National Institutes of Health, National Research Service Award T32-GM-07767 from the University of Michigan. We thank Dr. Daniel L. Klayman for his encouragement and for providing us with the compounds used in this study. We also thank Dr. Thomas Spector for his helpful advice on purification of the reductases and Deborah A. Hann for typing the manuscript.

\section{REFERENCES}

1. D. L. Klayman, J. F. Bartosevich, T. S. Griffin, C. J. Mason and J. P. Scovill, J. med. Chem. 22, 855 (1979).

2. D. L. Klayman, J. P. Scovill, J. F. Bartosevich and C. J. Mason, J. med. Chem. 22, 1367 (1979).

3. R. A. Casero, Jr., D. L. Klayman, G. E. Childs, J. P. Scovill and R. E. Desjardins, Antimicrob. Agents Chemother. 18, 317 (1980).

4. A. S. Dobek, D. L. Klayman, E. T. Dickson, Jr., J. P. Scovill and E. C. Tramont, Antimicrob. Agents Chemother. 18, 27 (1980).

5. A. S. Dobek, D. L. Klayman, E. T. Dickson, Jr., J. P. Scovill and C. N. Oster, Arzneimittel-Forsch. 33, 1538 (1983).

6. D. L. Klayman, J. P. Scovill, C. J. Mason, J. F. Bartosevich, J. Bruce and A. J. Lin, Arzneimittel-Forsch. 33, 909 (1983).

7. C. Shipman, Jr., S. H. Smith, J. C. Drach and D. L. Klayman, Antimicrob. Agents Chemother. 19, 682 (1981). 
8. C. Shipman, Jr., S. H. Smith, J. C. Drach and D. L. Klayman, Antiviral Res., in press.

9. E. C. Moore and A. C. Sartorelli, Pharmac. Ther. 24, 439 (1984).

10. L. Thelander and P. Reichard, A. Rev. Biochem. 48, 133 (1979).

11. G. H. Cohen, J. Virol. 9, 408 (1972),

12. B. M. Dutia, J. gen. Virol. 64, 513 (1983).

13. D. Huszar, S. Beharry and S. Bacchetti, J. gen. Virol. 64, 1327 (1983).

14. D. Huszar and S. Bacchetti, Nature, Lond. 302, 76 (1983).

15. V. G. Preston, J. W. Palfreyman and B. M. Dutia, J. gen. Virol. 65, 1457 (1984).

16. D. Huszar and S. Bacchetti, J. Virol. 37, 580 (1981).

17. Y. Langelier and G. Buttin, J. gen. Virol. 57, 21 (1981).

18. D. R. Averett, C. Lubbers, G. B. Elion and T. Spector, J. biol. Chem. 258, 9831 (1983).

19. E. A. Cohen, J. Charron, J. Perret and Y. Langelier, J. gen. Virol. 66, 733 (1985).

20. L. M. Nutter, S. P. Grill and Y.C. Cheng, Biochem Pharmac. 34, 777 (1985).

21. T. Spector and T. E. Jones, J. biol. Chem. 260, 8694 (1985).

22. K. Nakayama, J. L. Ruth and Y-C. Cheng, J, Virol. 43, 325 (1982)

23. C. Shipman, Jr., S. H. Smith, R. H. Carlson and J. C. Drach, Antimicrob. Agents Chemother. 9, 120 (1976).

24. C. Shipman, Jr., Proc. Soc. exp. Biol. Med. 130, 305 (1969).
25. T. Spector and D. R. Averett, Analyt. Biochem. 134 467 (1983).

26. K. Randerath and E. Randerath, J. Chromat. 16, 111 (1964)

27. G. L. Peterson, Analyt. Biochem. 83, 346 (1977).

28. A. Goldstein, Biostatistics: An Introductory Text, $\mathrm{p}$ 156. Macmillan, New York (1964).

29. R. W. Brockman, R. W. Sidwell, G. Arnett and S. Shaddix, Proc. Soc. exp. Biol. Med. 133, 609 (1970).

30. M. Dixon and E. C. Webb, Enzymes, 3rd Edn, p. 332 Academic Press, New York (1979).

31. D. J. Fox and K. E. Guire, MIDAS: Michigan Interactive Data Analysis System, p. 164. The Statistical Research Laboratory of The University of Michigan, Ann Arbor (1976).

32. M. J. M. Campbell, Coord. Chem. Rev. 15, 279 (1975).

33. E. C. Moore, M. S. Zedeck, K. C. Agrawal and A. C. Sartorelli, Biochemistry 9, 4992 (1970).

34. L. Thelander and A. Gräslund, J. biol. Chem. 258, 4063 (1983).

35. P. J. Preidecker, K. C. Agrawal, A. C. Sartorelli and E. C. Moore, Molec. Pharmac. 18, 507 (1980).

36. E. C. Moore, Cancer Res. 29, 291 (1969).

37. M. Ponce de Leon, R. J. Eisenberg and G. H. Cohen, J. gen. Virol. 36, 163 (1977)

38. C-H. Chang and Y-C. Cheng, Cancer Res. 39, 5081 (1979).

39. S. Eriksson, L. Thelander and M. Åkerman, Biochemistry 18, 2948 (1979).

40. J. G. Cory, Adv. Enzyme Regulat. 17, 115 (1978). 